\title{
Mesozoic fossils (>145 Mya) suggest the antiquity of the subgenera of Daphnia and their coevolution with chaoborid predators
}

\author{
Alexey A Kotov ${ }^{1 *}$ and Derek J Taylor ${ }^{2}$
}

\begin{abstract}
Background: The timescale of the origins of Daphnia O. F. Mueller (Crustacea: Cladocera) remains controversial. The origin of the two main subgenera has been associated with the breakup of the supercontinent Pangaea. This vicariance hypothesis is supported by reciprocal monophyly, present day associations with the former Gondwanaland and Laurasia regions, and mitochondrial DNA divergence estimates. However, previous multilocus nuclear DNA sequence divergence estimates at $<10$ Million years are inconsistent with the breakup of Pangaea. We examined new and existing cladoceran fossils from a Mesozoic Mongolian site, in hopes of gaining insights into the timescale of the evolution of Daphnia.

Results: We describe new fossils of ephippia from the Khotont site in Mongolia associated with the JurassicCretaceous boundary (about 145 MYA) that are morphologically similar to several modern genera of the family Daphniidae, including the two major subgenera of Daphnia, i.e., Daphnia s. str. and Ctenodaphnia. The daphniid fossils co-occurred with fossils of the predaceous phantom midge (Chaoboridae).

Conclusions: Our findings indicate that the main subgenera of Daphnia are likely much older than previously known from fossils (at least 100 MY older) or from nuclear DNA estimates of divergence. The results showing cooccurrence of the main subgenera far from the presumed Laurasia/Gondwanaland dispersal barrier shortly after formation suggests that vicariance from the breakup of Pangaea is an unlikely explanation for the origin of the main subgenera. The fossil impressions also reveal that the coevolution of a dipteran predator (Chaoboridae) with the subgenus Daphnia is much older than previously known - since the Mesozoic.
\end{abstract}

\section{Background}

The timescale of the evolution of some of the most successful freshwater microcrustacean groups such as copepods and cladocerans is poorly known or controversial. Both groups are comprised of small and often fragile species, whose fossilized body parts might easily be overlooked. Copepods appear be predisposed to weak fossilization as they are extremely rare in the subfossil and fossil record and apparently only preserved under very unusual circumstances such as oil seeps [1]. Tasch [2], however, reasoned (after conducting drying experiments of cladocerans on pond mud) that body parts of cladocerans should be well-preserved in freshwater

\footnotetext{
* Correspondence: alexey-a-kotov@yandex.ru

${ }^{1}$ AN Severtsov Institute of Ecology and Evolution, Leninsky Prospect 33, Moscow 119071, Russia

Full list of author information is available at the end of the article
}

sediments. Of course, the subfossils of cladoceran ephippia (modified moulting exuviae containing resting eggs) and heavily chitinized body parts are common in lacustrine sediments - fossilized cladoceran resting eggs had already been reported by 1968 from the Pliocene, the Miocene and the Eocene [3-6]. Tasch [2] "hunted thoroughly" for cladoceran fossils without success in Paleozoic freshwater sediments and later predicted that cladocerans probably arose during the Mesozoic. Proposals of Paleozoic records of cladocerans [7] turned out to be of non-cladoceran origin [8], supporting Tasch's hypothesis of a later origin for cladocerans. Later, authentic Mesozoic cladoceran fossils were discovered from several sites [8-14].

Still, for the cladoceran genus Daphnia O. F. Muller, 1785 (Cladocera: Anomopoda), there is a lack of reliable calibration points from either geographic or from fossil

\section{Biomed Central}


evidence. The present day geographic domination of former Gondwanaland regions by the subgenus Daphnia (Ctenodaphnia) Dybowski et Grochowski, 1895 and of former Laurasian regions by the subgenus Daphnia (Daphnia), and the reciprocal monophyly of each subgenus [15-17] could indicate an ancient vicariance event in the early Cretaceous $[18,19]$. But, the north-south hemispheric dichotomy of the subgenera in extant Daphnia is unapparent in the sparse fossil record - every Cenozoic record with fossilized ephippia from the northern hemisphere reports Ctenodaphnia-like fossils (China, Germany, Spain, and USA) [4,20,21]. Moreover, Daphnia ephemeralis (Schwartz et Hebert, 1985), the oldest member of the presumed Gondwanaland clade [15,17] is restricted to former Laurasia. The oldest fossils of the subgenus Daphnia are known from the northern hemisphere only at the German Lake Messel site (Eocene) where fossils of Ctenodaphnia are also recorded. Smirnov [11] assigned impression fossils of Mesozoic ephippia to the genus Daphnia (or "Daphnia-type"), but the subgenus was unassigned.

A deeper understanding of the timescale of daphniid evolution has implications beyond biogeography and systematics. Daphniids have become the model taxon for ecological genomics and the evolution of inducible defenses [22-24]. The best studied inducible defenses involve responses of daphniids to chemical cues resulting from predation by the phantom midge larvae (Chaoboridae) [25]. Numerous phenotypic responses (morphology, life-history, and behavior) have been reported from daphniids. Initial studies indicate that genomic control of inducible defenses is polygenic and complex [23,26,27], with a majority of responsive genes having no known homologs [23]. Indeed species of both major subgenera of Daphnia appear to possess complex genomic adaptations to predation by chaoborids $[24,25]$. The phantom midge family (Chaoboridae) has an excellent Mesozoic fossil record in Asian lake fossil beds with thousands of specimens known from at least five locations [28]. Does the timescale of co-evolution between Daphnia and phantom midges extend to the Mesozoic?

Without reliable independent calibrations, molecular estimates of the divergence of Daphnia have also been predictably conflicting. In general, estimates from mitochondrial genes appear consistent with a Mesozoic origin of the subgenera [17,29-31]. Nuclear estimates of divergence, however, have been dramatically lower than estimates from mitochondrial genes, a phenomenon that has been attributed to differences in the effective population sizes and responses to selection for the respective genomes. Nuclear DNA estimates of divergence based on observed mutation rates of Drosophila and Caenorhabditis elegans have yielded divergence times at 7.6
MY for the subgenera of Daphnia [32]. This young estimate of divergence requires that the mitochondrial DNA estimates and the conclusions of Richter and Wedmann [6], who assigned damaged ephippia from fish coprolites in Eocene deposits (about $47 \mathrm{Myr}$ ) to Daphnia (Daphnia) pulex and Daphnia (Ctenodaphnia) magna, to be spurious [33].

More evidence is needed to resolve the existing profound disagreements of the timescale of evolution for the genus Daphnia. Importantly, the ephippium has been identified as possessing important diagnostic characters for the subgenera [19]. In Daphnia (Daphnia) the ephippium is sub-triangular in shape (because the anterior half of the ephippium is deeper than the posterior half), with axes of two eggs perpendicular or sub-perpendicular to the dorsal margin (Figure 1a-b). In contrast, the ephippium of $D$. (Ctenodaphnia) Dybowski \& Grochowski, 1895 is usually D-shaped, with the axes of eggs being sub-parallel to dorsal margin (Figure 1c-e). The third subgenus, D. (Australodaphnia) Colbourne, Wilson et Hebert, 2006 represented now only by a single species, Daphnia occidentalis Benzie, 1986, has only a single egg in the ephippium [34]. We note that some extant Ctenodaphnia (Figure 2a-b) and all other daphniid genera, i.e. Simocephalus (Figure 2c-d) also have a single large egg in the ephippium.

Inspired by the relatively undamaged impression fossils of ephippia reported by Smirnov [11] from Mesozoic Mongolian sediments, we examined existing and new samples from this site. We report that there is fossil evidence for an ancient Mesozoic divergence of the subgenera of Daphnia. The evidence extends the age of the subgenera by about $100 \mathrm{MY}$ from existing fossils and by about 138 MY from nDNA mutation rate estimates. Further, the co-occurrence of fossils from the subgenera and from chaoborids indicates a coevolutionary history of predator and prey taxa that also dates to the Mesozoic.

\section{Results}

Limestone fragments with clear impressions were assigned specimen numbers and stored at the Palaeontological Institute of Russian Academy of Sciences. The number of impression fossils per fragment is given in parentheses below. Fragments with numbers 4307/2001 - 4307/2040 were previously discovered by Smirnov [9] and re-examined here; fragments with subsequent numbers were newly discovered by AAK and described below.

\section{Daphnia (Daphnia) sp.? \\ Material examined. 4307/2046 (2).}

Description. Lengths are $0.86 \mathrm{~mm}$ and $1.03 \mathrm{~mm}$. The ephippium is sub-triangular, relatively high (height/ 

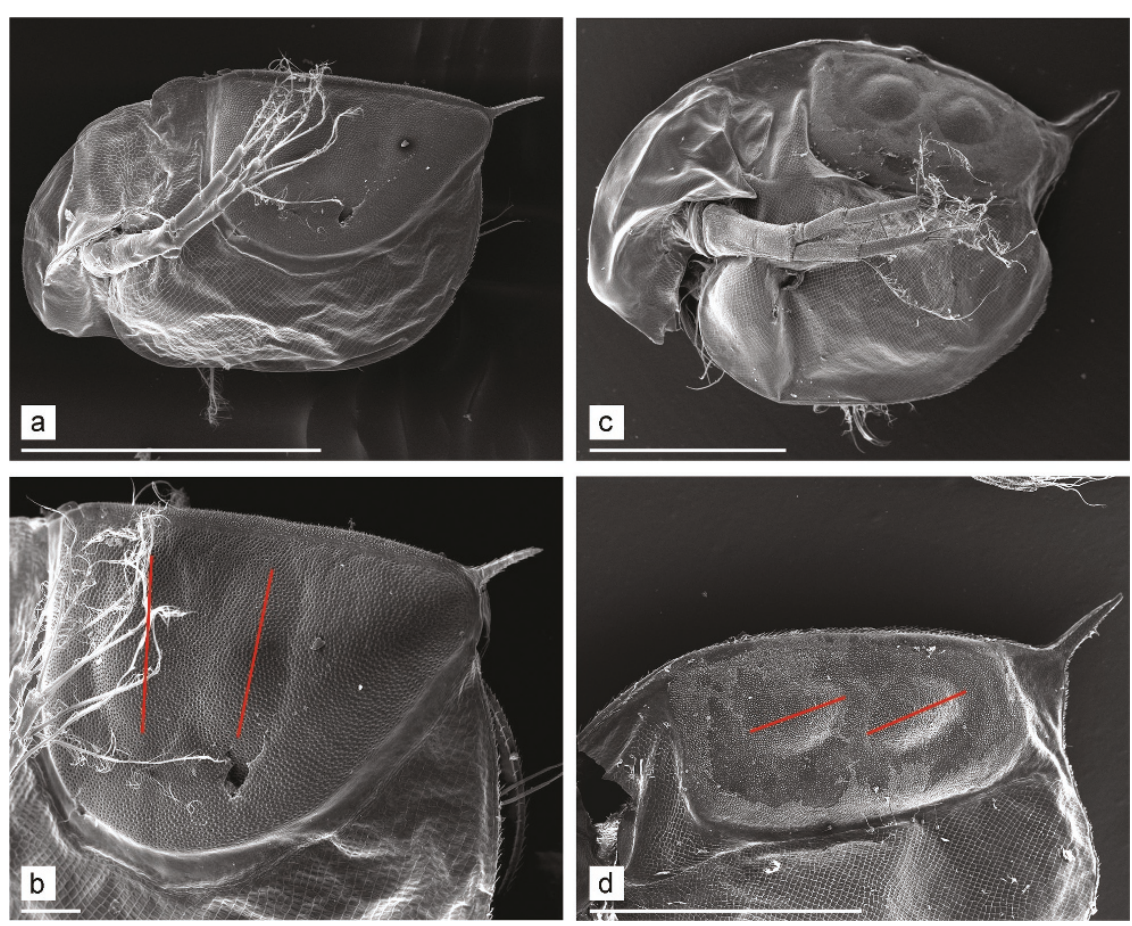

Figure 1 SEMs of ephippial females of extant Daphnia. a-b. Daphnia (Daphnia) pulex, general view of ephippial female and ephippium. c-d. Daphnia (Ctenodaphnia) magna, general view of ephippial female, ephippium and its sculpture. Red lines show the orientation of the egg axes. White scale bars: $1 \mathrm{~mm}$ for a, c-d; $0.1 \mathrm{~mm}$ for $\mathrm{b}$.
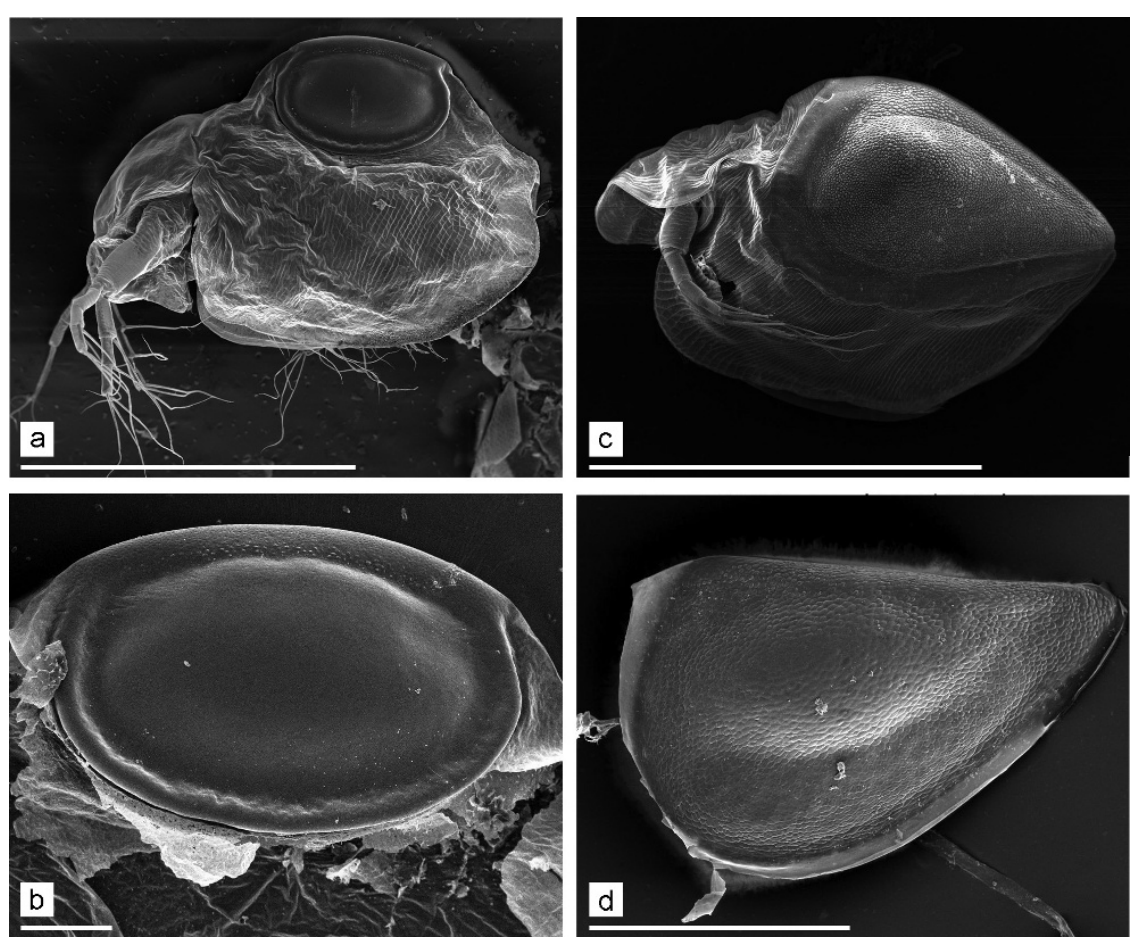

Figure 2 Single-egged ephippial females of Daphnia and Simocephalus. a-b. Daphnia (Ctenodaphnia) pusilla, general view of ephippial female and ephippium. c. Simocephalus exspinosus, ephippial female. d. Simocephalus vetulus, ephippium. Scales: $1 \mathrm{~mm}$ for a, c; $0.1 \mathrm{~mm}$ for b, d. 
length $=0.59$ and 0.63 ), with an almost straight dorsal margin. The caudal needle or spine is missing and there is a widely rounded antero-dorsal and postero-dorsal angle (Figure 3a). The dorsal portion of the ephippium is a non-reticulated, heavily-chitinized plate (Figure $3 \mathrm{~b}$ ). Much of the ephippial surface has inflated reticulation (Figure 3c). The axes of the two eggs are almost perpendicular to the dorsal margin.

\section{Daphnia (Ctenodaphnia) sp}

Material examined. 4307/2004 (2); 4307/2007 (1); 4307/2018 (1); 4307/2024 (1); 4307/2025 (1); 4307/2026 (1); 4307/2033 (1); 4307/2042 (4); 4307/2044 (2); 4307/ 2048 (1); 4307/2049 (2).

Description. Length 0.97-1.17 mm. The ephippia have a varying relative height (height/length $=0.50-0.69$ ), with a dorsal plate, and axes of eggs parallel to the dorsal margin. We found size differences among the ephippia of Daphnia (Ctenodaphnia), but the material is too scarce to designate species. Larger ephippia usually have a widely rounded antero-dorsal angle and a distinct caudal needle at the postero-dorsal angle. The surface has a well-developed sculpture, with patterns varying among individuals (Figures 3d-f, 4a-c). In contrast, the smaller ephippia have acute antero-dorsal and postero-dorsal angles lacking a caudal needle and surface sculpturing (Figure 4d).

\section{Daphniidae gen. sp. 1}

Material examined. 4307/2009 (1).

Redescription. Length $1.02 \mathrm{~mm}$. The ephippium is high, with a slightly convex dorsal margin, a widely rounded anterior margin and a triangular posterior margin (Figure 4e). The entire surface is covered with dorso-ventral striation. The axis of a single egg is located parallel to the dorsal margin, and the egg chamber occupies about half of the ephippium length.

Comments. This ephippium was named "of Moinatype" by Smirnov [11], but the generic determination is uncertain. Most probably, this is a daphniid ephippium, but a very primitive one. Recent species of Moina have ephippia with well-developed sculpture of different types [5]. In contrast, the ephippium from fragment 4307/ 2009 is only striated. Other daphniids, namely Ceriodaphnia and some species of Daphnia (Ctenodaphnia) (see Figure 2a-b) lay monoegged ephippia (in the case of Daphnia they are sometimes lacking a caudal needle or spine). So, the generic position of this ephippium is unclear.

\section{Simocephalus sp \\ Material examined. 4307/2026 (1); 4307/2042 (1).}

Redescription. The ephippium is elongated, with a straight dorsal margin, a widely rounded anterior margin and a fluently narrowing posterior portion. The surface is finely reticulated (Figure $4 \mathrm{f}$ ). The axis of a single, elongated egg is located parallel to the dorsal margin. The egg chamber occupies more than $2 / 3$ of ephippium length. Length: 1.02 and $1.10 \mathrm{~mm}$.

Comments. The ephippium from fragment 4307/2026 was justifiably named "of Simocephalus-type" by Smirnov [11], indeed, it is quite similar to the ephippia of recent species from this genus (Figure 2c-d). Among daphniids, the ephippium of Simocephalus is quite unique in possessing a fluently narrowing posterior portion and a large, elongated resting egg [35]. Although ephippia of recent species normally have well-developed sculpturing, weak sculpturing of the Mesozoic ephippia could be an artefact of impression fossil formation or of among-species variation.

\section{Discussion}

Our finding of ephippia from the Khotont site that are morphologically similar to the common subgenera of Daphnia, D. (Daphnia) and D. (Ctenodaphnia), indicates that these two subgenera potentially existed at the J-K boundary (at least $145 \mathrm{Mya}$ ). Our results also confirm the finding of Smirnov [11] that additional daphniid genera (i.e. Simocephalus) are present at this boundary. The fossils of Khotont likely extend the fossil record of the subgeneric divergence of Daphnia by about 100 MY.

The detection of the subgenus Ctenodaphnia in the northern hemisphere during the $\mathrm{J}-\mathrm{K}$ boundary poses a problem for the hypothesis of vicariance by the break up of the supercontinent Pangaea. The continental breakup had occurred by 155 MYA forming Laurasia and Gondwana, but the two lineages apparently cooccurred far from the presumed dispersal barrier in northern Laurasia by about 145 MYA. Under the "out of Gondwanaland" requirement for the current vicariance hypothesis, the subgenus Ctenodaphnia would have had to breach a more severe oceanic dispersal barrier than contributed to initial speciation, and colonize the most distant continent from Gondwanaland. This requires the unlikely transcontinental dispersal before the major dispersal vector of daphniids (modern birds) had evolved. Instead, the current fossil and phylogenetic evidence indicates that the break up of Pangaea is not associated with the origins of the main subgenera of Daphnia. Ctenodaphnia and Daphnia appear to have had a presence in Laurasia since the early Mesozoic (Figure 5). Ctenodaphnia are known from throughout much of the present northern hemisphere and one of the northern endemics, Daphnia ephemeralis, is likely the oldest known member of the Ctenodaphnia, with a basal position in the Ctenodaphnia phylogeny. D. ephemeralis also has a primitive morphology for the subgenus with the female having: (1) a very thick, almost 

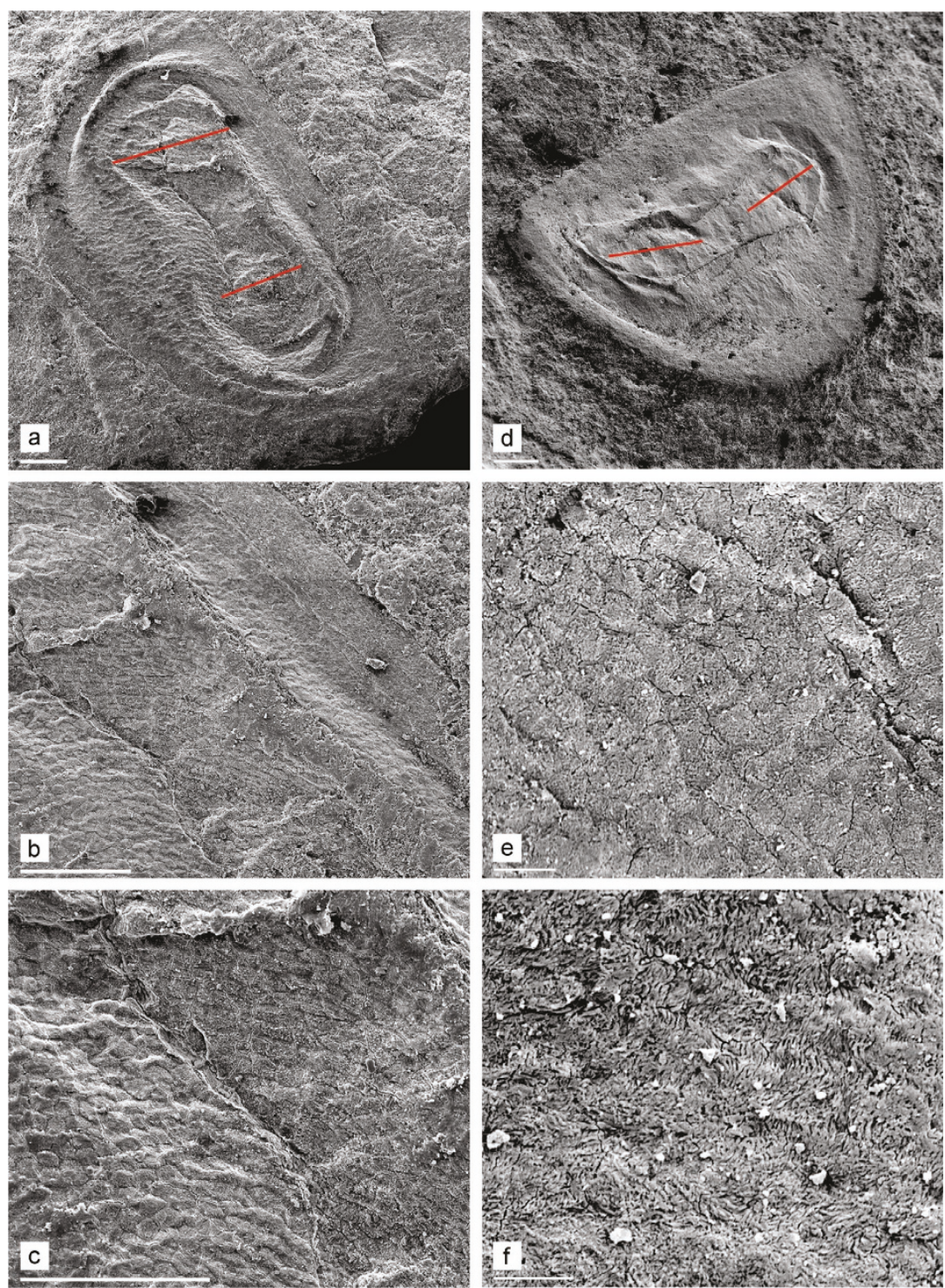

Figure 3 SEMs of Mesozoic ephippia of Daphnia from Khotont, Mongolia. a-c. Putative ephippium of Daphnia (Daphnia) from fragment 2046, its dorsal portion and reticulation. Note that the anterior half of the ephippium is deeper than the posterior half, giving a sub-triangular shape. d-f. Ephippium of Daphnia (Ctenodaphnia) from fragment 2018, reticulation and fine sculpture of valve. Red lines show the putative orientation of the egg axes. White scale bars: $0.1 \mathrm{~mm}$ for a, d; $0.01 \mathrm{~mm}$ for b-c, e-f.

rounded body; (2) no caudal needle in adults; (3) a rounded fornix; (4) a weakly developed rostrum; and (5) no posterior mid-line depression on the head shield and, as a result, a W-shape of the dorsocephalic suture (see [19] for terminology). Ctenodaphnia fossils have been found from the Pliocene of Nevada, USA, the Miocene of Spain, the Pliocene, Oligocene and Eocene of China, the Eocene of Germany, and here from the Mesozoic of Mongolia (Figure 5). No fossil Ctenodaphnia species are yet known from former Gondwanaland. Although the geographic distribution of known fossils and "basal" species appears inconsistent with Gondwanaland origins for
Ctenodaphnia, the role of extinction and differential fossilization in the formation of these patterns is unknown. It is clear that the age of our new fossils together with existing fossil evidence makes the hypothesis of Pangaearelated vicariance less likely.

Our results provide a case where both molecular dating (save the mtDNA estimates) and current biogeography appear to have been misleading regarding the timescale of evolution. Haag et al. [32] discuss potential reasons (error associated with estimates of mutation rate, number of generations per year, and population subdivision) for discrepancies between their nDNA 

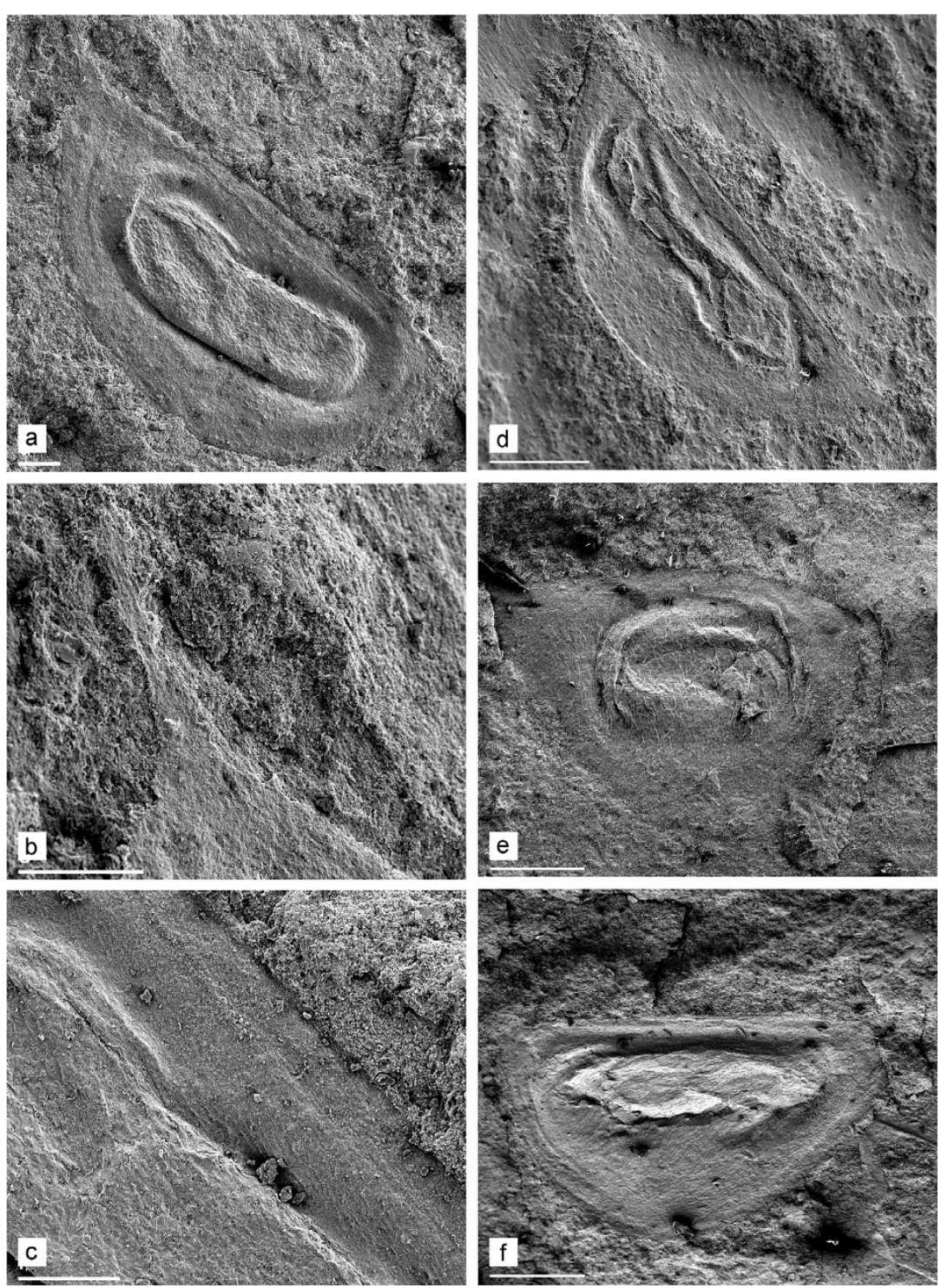

Figure 4 SEMs of Mesozoic daphniid ephippia from Khotont, Mongolia. a-c. Daphnia (Ctenodaphnia) from fragment 2048, its caudal needle and dorsal portion. d. Daphnia (Ctenodaphnia) from fragment 2044. e. Unknown daphniid from fragment 2009. f. Simocephalus from fragment 2026. Scales: $0.1 \mathrm{~mm}$ for $\mathrm{a}$, d-f; $0.01 \mathrm{~mm}$ for b-c.

dating and the existing mtDNA clock estimates (and now fossil estimates). The dominance of the southern hemisphere by the Ctenodaphnia when most Daphnia appear capable of among-continent dispersal remains a mystery. Presently, species of Daphnia s. str. prefer large lakes, while members of $D$. (Ctenodaphnia) occur most often in small temporary water bodies (although there are exceptions from this general rule). If this preference evolved early in the differentiation of the subgenera, the greater preference for non-lacustrine and temporary habitats in the Ctenodaphnia compared to Daphnia combined with priority effects are plausible explanations for the differential success of Ctenodaphnia in the southern hemisphere (see also [17]). In the large Mesozoic lake Khotont both subgenera were found together. But this finding does not mean that they cooccurred in a stable fashion. We cannot rule out the possibility that ephippia were introduced from the surrounding (permanent or temporary) lentic water bodies during some high water periods, or by some lotic waters. Most commonly, the contents of such small water bodies are not fossilised - we have palaeontological information from cladocerans largely from lakes.

We assumed that ephippial characters that represent subgenera of extant species also reflect the same subgenera in Mesozoic taxa. However, it is plausible that 


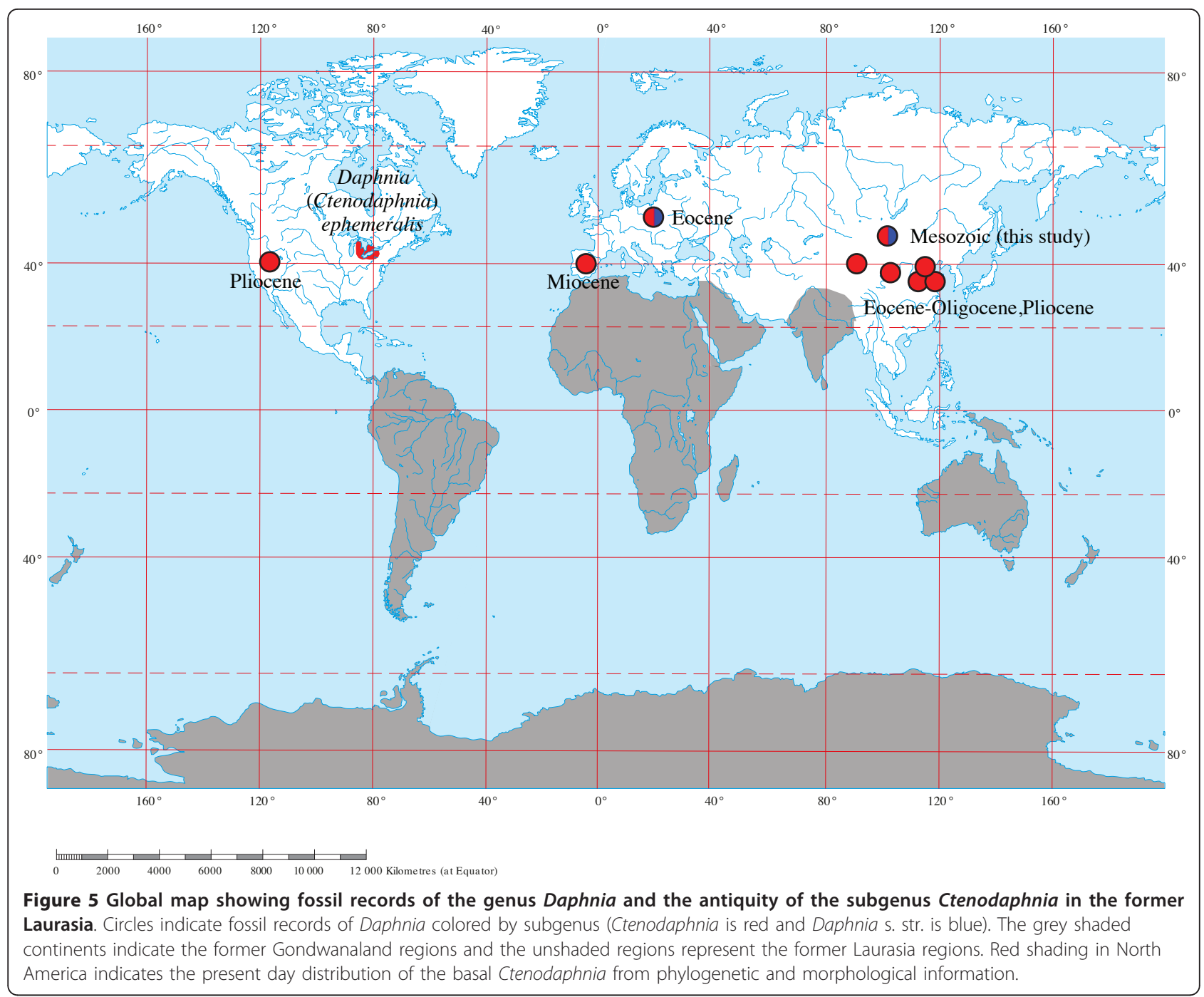

ephippial characters from extant subgenera are nondiagnostic in Mesozoic taxa. A scenario of independent origins for ephippial characters or ancestral polymorphisms might result in Mesozoic ephippia being uninformative for subgeneric reconstruction. However, the multiple origins of characters requires more evolutionary steps than character stability, and the ancestral polymorphisms scenario requires presumably independent diagnostic characters (shape and egg axis characters) to sort together. Ideally, more characters will be found from Mesozoic fossils of Daphnia that might address the hypothesis of evolutionary stability for diagnostic ephippial characters. Numerous cladocerans lacking an ephippium are reported for the same locality, namely, extinct prochydorids of three different species $[11,14]$ and a single antenna II of an undetermined ctenopod [12]. However, no complete adult or body part beyond ephippia is known from the daphniids of Khotont. The fact of poor preservation of daphniids compared to other cladocerans in bottom deposits is well-known [10]. Recently Richter and Baszio [36] demonstrated that the fine structure of Eocene daphniids, including limb structure, could be studied from fish coprolites - a type of fossil that is presently unknown from the Khotont. It seems clear that impression fossils yield well-preserved ephippia, but intact daphniid specimens will probably be best sought in fish coprolites from Mesozoic localities.

Remarkably, daphniids in Lake Khotont were found together with numerous (587 impressions were found) fossils of the dipteran (Chaoboridae) predator of daphniids $[37,38]$. Our results provide evidence that the phenotypic array of inducible defenses in Daphnia is more than a rapidly evolved response to predation. This important predator-prey group has been coevolving in freshwater for at least $145 \mathrm{MY}$. We expect that the antiquity of daphniidchaoborid coevolution will be reflected in both predator and host genomes. 


\section{Conclusions}

Our findings indicate that the main subgenera of Daphnia could be much older than previously known from fossils (at least $100 \mathrm{MY}$ older) or from nuclear DNA estimates of divergence. However, the results showing co-occurrence of the main subgenera far from the presumed Laurasia/Gondwanaland dispersal barrier shortly after formation suggests that vicariance from the breakup of Pangaea is an unlikely explanation for the origin of the main subgenera. The fossil impressions also reveal that the coevolution of a dipteran (Chaoboridae) predator with the subgenus Daphnia has been occurring much longer than previously known - since the Mesozoic.

\section{Methods}

Numerous limestone fragments were collected in the northern slope of Ukha Mount, $6 \mathrm{~km} \mathrm{~W}$ of Somon Khotont, Ara-Khangay Aymag (=Region) of Mongolia by the Expedition of the Palaeontological Institute of Russian Academy of Sciences (PIN) in 1980. Fragments from Khotont were taxonomically identified by the staff of PIN. Relative dating based on the examination of several thousand index fossils of insects (dipteran insects, for example, were represented by 948 impressions), assigned the present fragments to the Jurassic/ Cretaceous boundary [38] at about 145 Mya. Some cladocerans from this locality have been previously studied $[11,12,14]$.

For the present work, fourteen limestone fragments with 24 comparatively clear impressions of daphniid ephippia, seen by Smirnov [11] or subsequently found on fragments with other animal impressions, were selected. Micrographs were taken using the scanning electron microscope CAM SCAN MB2300 after coating with gold.

\section{Acknowledgements and funding}

We are grateful to Dr. A. G. Ponomarenko, Dr. D. E. Shcherbakov and Dr. E. D. Lukashevich (PIN) for their hard work to sort fossils, supplying us with material, and valuable consultations. Many thanks to Prof. N. N. Smirnov for help during different phases of our work, and late Mr. V. N. Antropov for technical assistance with SEM. We thank Dr. A. Petrusek and an anonymous reviewer for helpful comments. This study is partly supported by the Russian Foundation for Basic Research (grants 09-04-00201-a and 09-0490213$\mathrm{MOH} \Gamma_{\text {_a }}$ for AAK), Russian Biodiversity Programme (for AAK) and US National Science Foundation grant PEET (project DEB-0331095).

\section{Author details}

${ }^{1}$ AN Severtsov Institute of Ecology and Evolution, Leninsky Prospect 33, Moscow 119071, Russia. ${ }^{2}$ Department of Biological Sciences, The State University of New York at Buffalo, Buffalo, NY 14260, USA.

\section{Authors' contributions}

AAK and DJT conceived the study and co-wrote the paper. Both authors read and approved the final manuscript.

Received: 3 March 2011 Accepted: 19 May 2011 Published: 19 May 2011

\section{References}

1. Selden PA, Huys R, Stephenson MH, Heward AP, Taylor PN: Crustaceans from bitumen clast in Carboniferous glacial diamictite extend fossil record of copepods. Nat Commun 2010, 1:50.

2. Tasch P: Branchiopoda. In Treatise of Invertebrate Paleontology. Part $R$, Arthropoda. Volume 4. Edited by: Moore RC. Boulder, Colorado: Geological Society of America and Lawrence, Kansas: University of Kansas Press; 1969:128-191.

3. Frey DG: Phylogenetic relationships in the family Chydoridae (Cladocera). Proceedings of Symposium on Crustacea. Marine Biology Association of India: 1215 January 1965, Part 1; Ernakulam 1967, 29-37.

4. Dickinson KA, Swain FM: Late Cenozoic freshwater Ostracoda and Cladocera from northeastern Nevada. J Paleontol 1967, 41:335-350.

5. Goulden CE: The systematics and evolution of the Moinidae. Trans Amer Phil Soc Philadelphia, N. Ser 1968, 58:1-101.

6. Richter G, Wedmann S: Ecology of the Eocene Lake Messel revealed by analysis of small fish coprolites and sediments from a drilling core. Paleogeogr Paleoclimatol Paleoecol 2005, 223:147-161.

7. Smirnov NN: Cladocera (Crustacea) of Permian deposits from Eastern Kazakhstan. Paleontol Zh 1970, 3:95-100.

8. Kotov AA: Jurassic Cladocera (Crustacea, Branchiopoda) with a description of an extinct Mesozoic order. J Nat Hist 2007, 41:13-37

9. Smirnov NN: A new species of the genus Archedaphnia (Crustacea, Cladocera) from Jurassic deposits of Transbaikalia. Paleontol Zh 1971, 3:119-121.

10. Fryer G: A daphnid ephippium (Branchiopoda: Anomopoda) of Cretaceous age. Zool J Linn Soc-Lond 1991, 102:163-167.

11. Smirnov NN: Mesozoic Anomopoda (Crustacea) from Mongolia. Zool $\mathrm{J}$ Linn Soc-Lond 1992, 104:97-116.

12. Kotov AA, Korovchinsky NM: First record of fossil Mesozoic Ctenopoda (Crustacea, Cladocera). Zool J Linn Soc-Lond 2006, 146:269-274.

13. Kotov AA: New finding of Mesozoic ephippia of the Anomopoda (Crustacea: Cladocera). J Nat Hist 2009, 43:523-528.

14. Kotov AA: A revision of the extinct Mesozoic family Prochydoridae Smirnov, 1992 (Branchiopoda: Cladocera) with a discussion of its phylogenetic position. Zool J Linn Soc-Lond 2009, 155:253-265.

15. Omilian AR, Taylor DJ: Rate acceleration and long-branch attraction in a conserved gene of cryptic daphniid (Crustacea) species. Mol Biol Evol 2001, 18:2201-2212.

16. Ishida S, Kotov AA, Taylor DJ: A new divergent lineage of Daphnia (Cladocera: Anomopoda) and its morphological and genetical differentiation from Daphnia curvirostris Eylmann, 1887. Zool J Linn SoCLond 2006, 146:385-405.

17. Adamowicz SJ, Petrusek A, Colbourne JK, Hebert PDN, Witt JDS: The scale of divergence: a phylogenetic appraisal of intercontinental allopatric speciation in a passively dispersed freshwater zooplankton genus. Mol Phylogen Evol 2009, 50:423-436.

18. Hebert PDN: The population biology of Daphnia (Crustacea, Daphniidae). Biol Rev 1978, 53:387-426.

19. Benzie JAH: The genus Daphnia (including Daphniopsis)(Anomopoda: Daphniidae). Ghent: Kenobi Productions and Leiden: Backhuys Publishers; 2005.

20. Lai XR, Li YP: Ephippia of Cladocera from Tertiary of China. Acta Palaeontol Sin 1987, 26:171-180.

21. Peñalver $E$, Martínez-Delclòs $X$, De Renzi M: Registro de pulgas de agua [Cladocera: Daphniidae Daphnia (Ctenodaphnia)] en el Mioceno de Rubielos de Mora (Teruel, España). In Comunicaciones de la Il Reunión de Tafonomía y Fosilización, 13-15 June 1996; Zaragoza. Edited by: Melendez G, Blasco F. Zaragoza: Institucion Fernando El Catolico; 1996:311-317.

22. Petrusek A, Tollrian R, Schwenk K, Haas A, Laforsch C: A "crown of thorns" is an inducible defense that protects Daphnia against an ancient predator. PNAS 2009, 106:2248.

23. Colbourne JK, Pfrender ME, Gilbert D, Thomas WK, Tucker A, Oakley TH, Tokishita S, Aerts A, Arnold GJ, Basu MK, et al: The ecoresponsive genome of Daphnia pulex. Science 2011, 331:555-561.

24. Ebert D: Genomics. A genome for the environment. Science 2011, 331:539-540.

25. Tollrian R, Leese F: Ecological genomics: steps towards unraveling the genetic basis of inducible defenses in Daphnia. BMC Biol 2010, 8:51.

26. Schwarzenberger A, Courts C, von Elert E: Target gene approaches: Gene expression in Daphnia magna exposed to predator-borne kairomones or 
to microcystin-producing and microcystin-free Microcystis aeruginosa. BMC Genomics 2009, 10:527.

27. Miyakawa H, Imai M, Sugimoto N, Ishikawa Y, Ishikawa A, Ishigaki H, Okada Y, Miyazaki S, Koshikawa S, Cornette R, Miura T: Gene up-regulation in response to predator kairomones in the water flea, Daphnia pulex. BMC Dev Biol 2010, 10:45

28. Lukashevich ED: Larvae - a key to evolution of Culicoidea (Diptera) in the Mesozoic. Alavesia 2008, 2:59-72.

29. Lehman N, Pfrender ME, Morin PA, Crease TJ, Lynch M: A hierarchical molecular phylogeny within the genus Daphnia. Mol Phylogenet Evol 1995, 4:395-407.

30. Taylor DJ, Hebert PDN, Colbourne JK: Phylogenetics and evolution of the Daphnia longispina group (Crustacea) based on 12S rDNA sequence and allozyme variation. Mol Phylogenet Evol 1996, 5:495-510.

31. Schwenk K, Posada D, Hebert PDN: Molecular systematics of European Hyalodaphnia: the role of contemporary hybridization in ancient species. P Roy Soc Lond B 2000, 267:1833-1842.

32. Haag CR, MCTaggart SJ, Didier A, Little TJ, Charlesworth D: Nucleotide polymorphism and within-gene recombination in Daphnia magna and D. pulex, two cyclical parthenogens. Genetics 2009, 182:313-323, 9.

33. Kotov AA, Taylor DJ: A new African lineage of the Daphnia obtusa group (Cladocera: Daphniidae) disrupts continental vicariance patterns. J Plankton Res 2010, , 32: 937-949.

34. Colbourne JK, Wilson CC, Hebert PDN: The systematics of Australian Daphnia and Daphniopsis (Crustacea: Cladocera): a shared phylogenetic history transformed by habitat-specific rates of evolution. Biol J Linn SoC 2006, 89:469-488.

35. Orlova-Bienkowskaja MY: Daphniidae: genus Simocephalus. Leyden: Backhuys; 2001.

36. Richter G, Baszio S: Traces of a limnic food web in the Eocene Lake Messel - a preliminary report based on fish coprolite analyses. Paleogeogr Paleoclimatol Paleoecol 2001, 166:345-368.

37. Lukashevich ED: New Mesozoic Chaoboridae of Mongolia (Diptera: Chaoboridae). Paleontol Zh 1996, 4:55-60.

38. Rasnitsyn AP, Quicke DLJ, (Eds): History of insects. Kluwer Academic Publishers: Dordrecht, Boston and London; 2002.

doi:10.1186/1471-2148-11-129

Cite this article as: Kotov and Taylor: Mesozoic fossils ( $>145$ Mya) suggest the antiquity of the subgenera of Daphnia and their coevolution with chaoborid predators. BMC Evolutionary Biology 2011 11:129.

\section{Submit your next manuscript to BioMed Central} and take full advantage of:

- Convenient online submission

- Thorough peer review

- No space constraints or color figure charges

- Immediate publication on acceptance

- Inclusion in PubMed, CAS, Scopus and Google Scholar

- Research which is freely available for redistribution 